\title{
Why Is Kaizen Critical for Developing Countries?: Kaizen as a Social Innovation in the Era of Global Inequality
}

\author{
Go Shimada
}

\section{INTRODUCTION}

One of the most important global issues we face today is rising inequality in both developed and developing countries (Piketty 2014). Even if the inequality between countries has converged with the economic growth of emerging states, domestic inequality has worsened (Milanovic 2016), so the global economy today faces convergence and divergence at the same time. In regional terms, even if the overall economic gap has lessened, African countries still lag behind those in other regions. To change this situation, industrial sector development is certainly important, but to catch up, what African countries need to do is twofold. The first is to move their production possibility frontier (PPF) outward (movement of the PPF curve itself). For this, the best performing firms need to develop technological and/or production innovations. They can also introduce new technology and/or production methods from developed countries. These moves will allow their production possibility frontier to expand.

G. Shimada $(\bowtie)$

School of Information and Communication, Meiji University, Tokyo, Japan e-mail: go_shimada@meiji.ac.jp

(C) The Author(s) 2020

A. Hosono et al. (eds.), Workers, Managers, Productivity, https://doi.org/10.1007/978-981-15-0364-1_4 
The second way is to assist average firms to reach their production possibility frontier using existing technology (movement toward the frontier). A number of researchers (Baily and Solow 2001; Baily et al. 1992) have discovered that most firms operate well below their optimum level, compared with the best performing firms in the same industry. In other words, there is a huge and persistent difference in productivity between the leading and average firms in an industry (Stiglitz and Greenwald 2015). And, internal technological breakthrough innovation does not occur very often. Rather, most firms adopt proven technologies and try to catch up to the leading firms.

Both the movement of the PPF itself and the movement of individual firms toward the frontier can accelerate the economic growth of Africa and reduce the economic gap with developed countries. However, these changes may not be enough to tackle the issue of rising inequality in each country. We cannot expect the benefit of industrial development or firm growth to easily trickle down to the poor. Then, how can we make industrial development work for the poor? More precisely, can Kaizen contribute to solving the issue of inequality for each country? This chapter tries to answer this question looking back at Japan's experience.

\section{In the Era of Declining Labor Share in GDP: TOWARD SOCIAL INNOVATION}

Innovation is the source of economic growth. The Nobel Laureate Robert Solow $(1956,1957)$ showed that technological progress is the source of economic growth, rather than capital accumulation and increases in labor. Leapfrog innovation is important. We, however, need to remember that most of the innovations are small and incremental changes. These changes include both technological and production processes. These are not dramatic, but they are fundamental to the everyday operation of firms. It is also important to grow in the long run, not just enjoy short-term growth from innovation. That is why, Kenneth Arrow analyzed technological progress as focusing not only on research and development (1962a) but also on learning by doing (1962b).

As Stiglitz and Greenwald (2015) discussed, although technological and production innovations are important, they often increase just private returns, not social returns. There are reasons for this. First, the large firms in developed countries are more able to produce innovations compared with small and medium enterprises (SMEs) and firms in developing coun- 
tries. This is because they have more financial resources. Since their market is bigger than that of the SMEs, there are economies of scale for large firms in innovation.

Second, the first innovators, which are often large firms as discussed, can enjoy a monopoly over this new technology under strict intellectual property regimes (e.g., WTO/TRIPS [World Trade Organization/TradeRelated Aspects of Intellectual Property Rights]). As is well known in respect of monopolistic competition, firms produce less than the social optimum and increase the price whenever they can. This happens to many pharmaceutical drugs, which are essential for the lives of people in developing countries but are not affordable for the poor.

Third, under monopolistic competition, $R \& D$ investment in the area is often reduced. New innovations may be created based on existing technology, but without access to the technological information, it is hard to make investment within firms, especially in small and medium enterprises and firms in developing countries. Thus, future production will be smaller than the socially desirable level. In this contest, Kaizen can bring production innovation for firms without cost, and has very large spillover effects from the methods of production it advocates across sectors (institutional spillover). While the costs include more than just investment cost, there are no patent use costs as Kaizen is not patented.

As Fig. 4.1 shows, to increase productivity two types of innovation are required: production innovation and technological innovation. For a firm

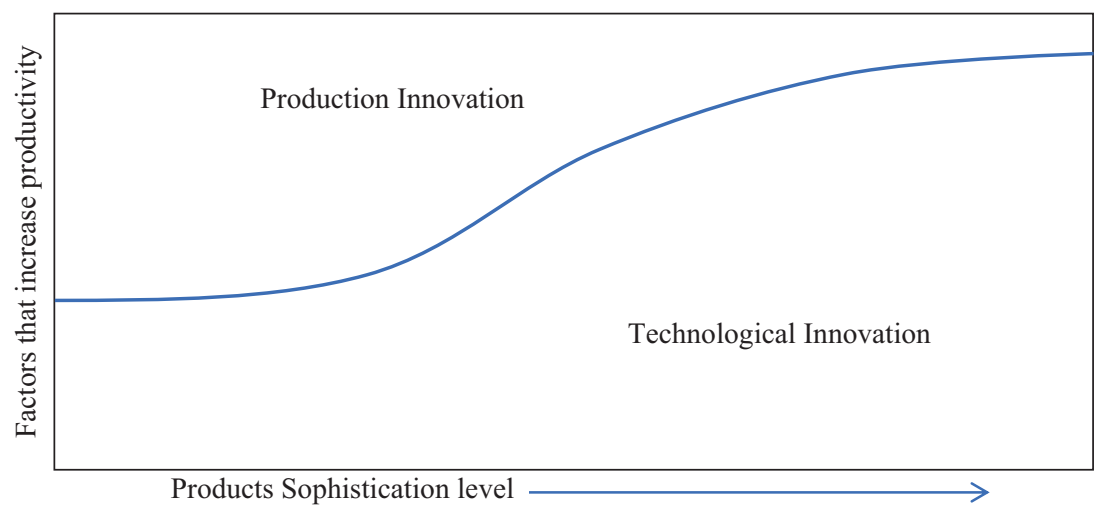

Fig. 4.1 Factor to increase productivity and types of innovation. (Source: Author) 
producing basic products, changes in production processes are required for an increase in productivity. As the sophistication level of products goes up, technological innovation becomes more important. In other words, Kaizen is more important for many small and medium firms that produce relatively less sophisticated products, allowing them to improve their productivity.

However, productivity growth is a double-edged sword. This is because, on the one hand, although it improves a firm's performance, on the other, it means firms can operate with fewer workers (Shimada 2015a, 2017a, 2018a, 2019; Shimada and Sonobe 2018; Higuchi and Shimada 2019). Further, since most technological innovations tend to be labor saving technologies, productivity growth could have negative consequences on the lives of workers if they lose their jobs. It is important to consider the distributional aspect of productivity growth. Figure 4.2 shows the share of labor compensation in gross domestic product (GDP) over the last two decades for selected countries. As is shown, there is declining trend. This means that the share of income distributed to workers in GDP is decreasing, and this is a global trend. In the age of rising inequality, the distributional aspect of productivity growth thus becomes very important.

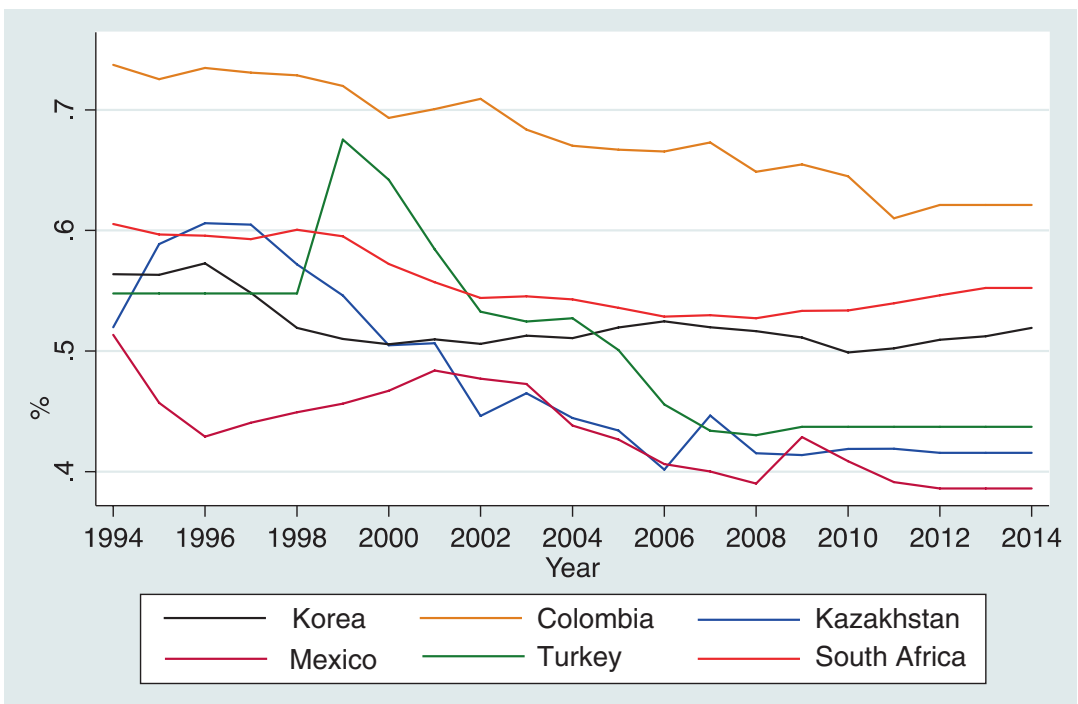

Fig. 4.2 Share of labor compensation in GDP at current national prices. (Source: Author, based on Penn World Table 9.0) 
Then, the question comes into mind could Kaizen contribute to this? The next section will examine this, analyzing how Kaizen worked in Japan when it was introduced, and paying special attention to its impact on labor.

\section{US AID TO JAPAN: JAPAN'S EXPERIENCE INTRODUCING KaIzen to Create Social InnOvation}

Japan introduced Kaizen in 1955 with assistance from the United States. As we will see in detail, there were three different aims for that introduction by each stakeholder: Japanese firms; the United States; and labor (Shimada 2015a, 2017a, 2018a, b, 2019; Shimada and Sonobe 2018; Higuchi and Shimada 2019). First, for Japanese firms, the main objective was to increase production with less labor. Because of World War II, the production capacity of Japanese firms was much lower than in the pre-war period. At the same time, the labor movement using confrontational methods such as strikes was very active. Under this condition, it was difficult for Japanese firms to meet market demands. So, for firms, there was a huge demand to increase productivity.

Second, for the United States, there were two objectives. Initially, after World War II the main objective was to democratize Japan, dismantling large enterprises and, at the same time, promoting small and medium enterprises and the labor movement (Shimada 2018a). After the start of the cold war though, the objective changed toward keeping labor unions on-side and away from the Soviet bloc. Third, for labor unions, when US aid was decided, they were against the productivity movement, because they feared that their jobs would be lost with increasing productivity. However, as they kept negotiating with employers, they started to secure wage increases, which raised their living standards considerably.

In the next section, we will examine why Japan introduced Kaizen from these three different perspectives. We will also examine what kind of impact this had on Japanese society. To begin this analysis, we start by looking at the situation existing soon after World War II.

\subsection{Economic Policy During the United States' Occupation of Japan: The GHQ Policy Toward Economic Recovery}

GHQ policy had a huge impact on how Japan recovered from the devastation of World War II, not just in the short term, but over the long term until today. The GHQ, especially the GS (Government Section), had a 
clear policy to transform Japan from the old regime to a democratic, nonautocratic and non-militarized country. The GS was the hub for making these policies. A lot of the New Dealers who participated in the New Deal program of US President Roosevelt worked in the GS, ${ }^{1}$ and the occupation policies strongly reflected their political and economic views. Further, it had strong influence on industrial policies in Japan, as we will review in the next section. GS personnel were very radical, and in his memoir, former Prime Minister Yoshida Shigeru even called them "radical elements," and mentioned that they used Japan as a laboratory for testing their theories. $^{2}$

The old systems that GHQ considered necessary to change were: (1) political system and bureaucracy; (2) conglomerates (zaibatsu) which were controlled by family-owned holding companies; and (3) landlordism. These were considered to have supported Japan's militarism during the war. Based on notions of democratic reforms, the GHQ launched a series of policies to: (a) purge leaders and public officials who were responsible for the war; (b) abolish the internal security law, giving freedom of expression to the mass media, political parties and organizations, such as labor unions; (c) dissolve conglomerates and trusts; and (d) reform land ownership. ${ }^{3}$ These policies changed the political balance between the existing old regime and the leftist political parties, small and medium enterprises, and the labor movement (Tsunekawa 2010), and had a huge influence on industrial policy, which will be discussed next as the essence of Japan's inclusive economic growth in the post-war period.

\subsection{The Necessity to Improve Productivity for Recovery After the $\mathrm{War}^{4}$}

\subsubsection{Hyperinflation}

After the war, Japan suffered very serious hyperinflation. There were two reasons for this: first, Japan's production capacity was totally destroyed by bombing during the war, as Table 4.1 shows. ${ }^{5}$ Due to this, supplies of almost all goods were affected by shortages. To be more precise, almost no products were available at the regulated market price, and prices went up in the black market; second, the money supply was increased to monetize the huge stock of war debts to victorious countries. This very rapid money supply increase was another reason for hyperinflation. One of the policy priorities for the Japanese government, therefore, was to increase 
Table 4.1 Indices of industrial production, 1946-1947

\begin{tabular}{lll}
\hline Period & SCAP index $(1930-1944=100)$ & United nations index $(1937=100)$ \\
\hline 1946 & 31.8 & 19 \\
January & 17.7 & 11 \\
August & 35.9 & 22 \\
December & 38.1 & 23 \\
1947 & $38.8^{\text {a }}$ & 25 \\
January & 33.6 & 20 \\
August & 40.0 & 25 \\
December & - & 27 \\
\hline
\end{tabular}

Source: Japanese Economics Statistics, GHQ, SCAP (Supreme Commander for the Allied Powers), September 1947, 7-9; and Monthly Bulletin of Statistics, United Nations, February 1948, 26 (Bisson 1949)

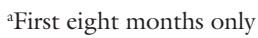

production to bring basic food and necessary goods to people and to stabilize inflation. $^{6}$

During the same period, the dissolution of the conglomerates was implemented. Bisson, the top economic analyst of the GS at GHQ, thought that during the war Japanese cabinets were largely controlled by conglomerates and industrial capitalists (Schonberger 1980). In 1947, the GHQ required the stock owned by the conglomerates' holding companies to be sold to the public. ${ }^{7}$ At the same time, the GHQ adopted policies to promote SMEs as a counter force to the former conglomerates' larger firms. Policies such as the establishment of an SME agency to support new SMEs and help them compete with the erstwhile-conglomerate companies; the enforcement of anti-monopoly laws in 1947; and the establishment of the Japan National Finance Corporation for SMEs in 1953 to support SMEs financially were introduced. These SME-related policies made Japan's industrial policy more inclusive, as we will see later.

\subsubsection{Labor Movement}

Other than hyperinflation, there was another reason underpinning the necessity for productivity increases. While increase in production was the policy priority in Japan at this time, the labor movement also became very active soon after the war. This was also related to the GHQ policy mentioned above. The GHQ released communist political leaders such as Tokuda Kyuichi from prison as a part of its policy to give freedom of expression to mass media, political parties, and organizations. As soon as 
they were released, they attracted popular support. ${ }^{8}$ At the same time, Article 28 of the Constitution of Japan promulgated in November 1946 guaranteed the three rights of work (the right of workers to organize, to bargain, and to act collectively).

Against the GHQ's intentions however, the labor movement became too active and radical. ${ }^{9}$ With the establishment of the People's Republic of China in 1949 and the start of the Cold War between the United States and the Soviet Union, the GHQ changed its stance on the labor movement and tried to repress it. ${ }^{10}$ However, the labor movement continued to spread all over Japan. As the labor movement became stronger, conflict between the government and labor movement increased day by day. In 1950, the GHQ started its red purge of government and journalism, as well as private companies (for a detailed discussion on this topic, please refer to Shimada 2018a). Finally, private companies were under pressure to increase production to tackle the shortage of all kinds of goods from basic food to steel in the market and to increase productivity with less labor because of the strong labor union movement. Otherwise, the shortage of labor would impede any production increase.

\subsubsection{Cold War}

As described above, there was strong incentive for private companies to increase productivity. At the same time, during this period the United States was enthusiastic about transplanting the productivity movement not only to Japan but also to war-torn Europe through their aid programs such as the Marshall Plan and the Point Four Program. ${ }^{11}$ The main objective for the United States was to influence labor unions, keeping them as social democrat and not allowing them to become communist (Sovietization). Therefore, it was natural for the US government to support the productivity movement in Japan, as Japan was strategically important in East Asia. In 1951, a plan was drafted in Japan to establish a productivity organization with support from the FOA (Foreign Operation Administration) of the US government (Shimada 2015a, 2017a, 2018a, 2019; Shimada and Sonobe 2018; Higuchi and Shimada 2019). ${ }^{12}$

\subsubsection{Creating Social Innovation}

The plan to introduce the productivity movement met fierce opposition from labor unions (through the Sobyo or General Council of Trade Unions of Japan). The unions feared that with increased production, jobs could be cut, and work intensified for employees. So, in 1955 they declined to participate in the US-assisted productivity movement. However, as it was 
suggested by the United States that there be three partners (government, private companies, and labor), labor was essential for the country to receive aid from the United States. As the aid plan was stalled, long negotiations between the three sides were held. Finally, as a compromise, the JPC (Japan Productivity Center) issued three guiding principles for the productivity movement, influenced by the Philadelphia declaration of the ILO (International Labor Organization) of 1944. Based on this, labor agreed to participate in the movement, stressing the importance of "industrial democracy." With this agreement, many bureaucrats and business personnel studied productivity improvement with support from the United States. This significantly helped Japan's manufacturing sector to grow, and the Toyota Production System (TPS) or Kaizen was born from the productivity movement and spread all over Japan.

The principles are as follows:

\section{Expansion of employment}

In the long term, improving productivity should lead to expanding employment. However, from the standpoint of the national economy, a public-private partnership is essential in formulating valid policies to prevent the unemployment of surplus personnel through job relocations or other measures.

\section{Cooperation between labor and management}

Labor and management must cooperate in researching and discussing specific methods to improve productivity in consideration of specific corporate circumstances.

\section{Fair distribution of the fruits of productivity}

The fruits of productivity should be distributed fairly among labor, management, and consumers in line with the state of national economy.

There were dual aims. One was to enhance competitiveness to expand markets by utilizing resources effectively and scientifically, while at the same time reducing production costs. The other was to boost employment and to enhance real wages and the standard of living. The expansion of employment and wages was very important to improve living standards in 
Japan. This also changed the nature of labor-management relations from combative to collaborative. Without this collaborative partnership between labor and management, high economic growth may not have occurred. In 1960, Prime Minister Hayato Ikeda also announced a plan to double the income of the Japanese people in ten years. This collaborative relationship between employers and employees was the basis of the inclusive economic growth of Japan.

\section{Impacts on Wage: Kaizen as Social Innovation}

Then, what were the impacts on labor, especially on wage and living standards? Figure 4.3 shows the labor compensation in Japan's GDP by firm size. As it is clear from the figure, labor share has been steadily increasing in both large firms and SMEs since the 1960s in Japan. This is in sharp contrast with the current global trend seen in Fig. 4.1, which shows a declining trend in labor share.

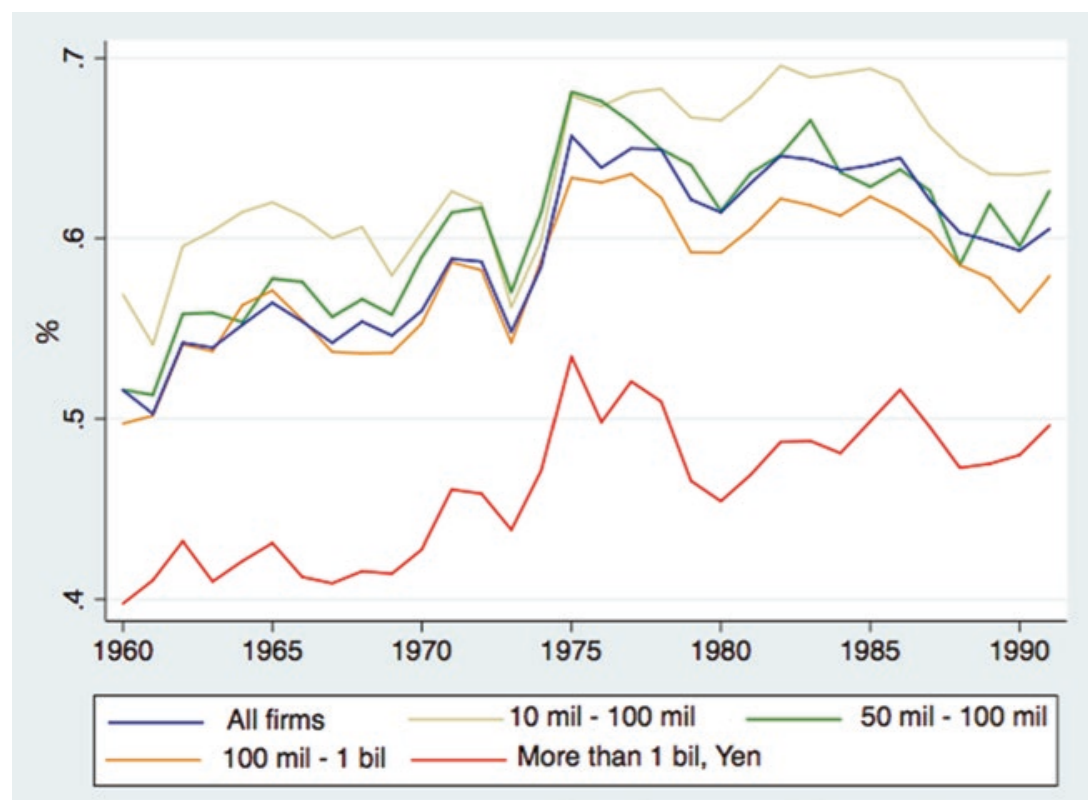

Fig. 4.3 Share of labor compensation in Japan's GDP by firm size. (Source: Author, based on Penn World Table 9.0) 


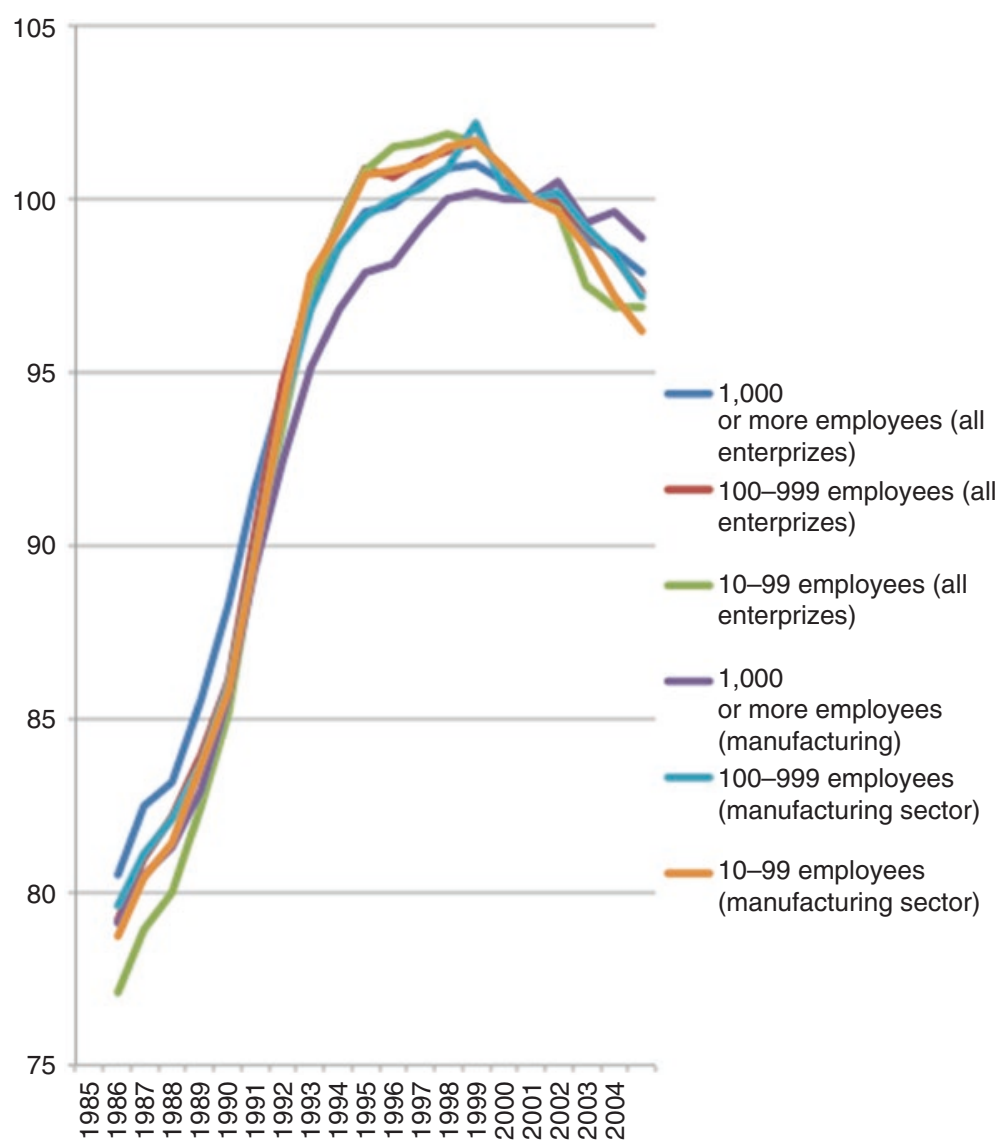

Fig. 4.4 Wage rate index of scheduled cash earnings and bonus in number of months by industry and by size of enterprise (1985-2004). (Source: Author, based on information from the Statistics and Information Department, Minister's Secretariat, Ministry of Health, Labor and Welfare)

Figure 4.4 also shows that the wage rate index by industry and by size of enterprise increased at the same rate not only for large companies but also for micro and small enterprises. As wages increased, living standards have improved in Japan.

As shown in Fig. 4.5, as GDP per capita increased, the ratio of households on welfare rapidly decreased from around $40 \%$ in 1952 to around 


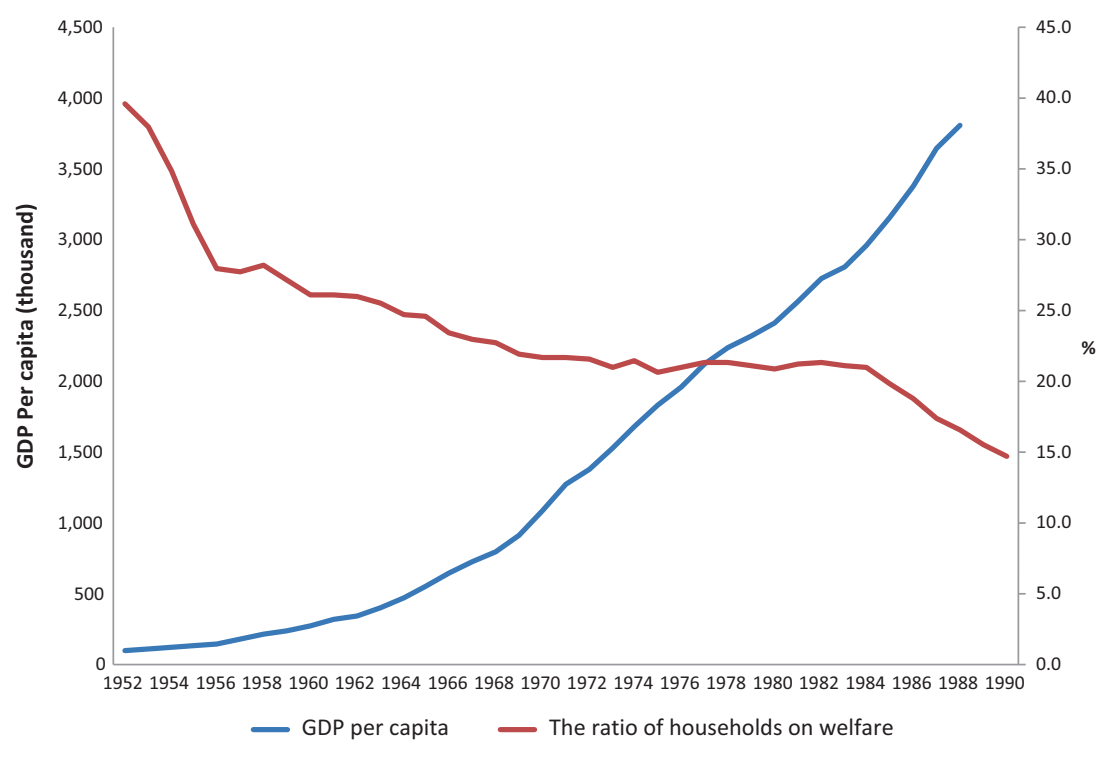

Fig. 4.5 GDP per capita and households on welfare of Japan since 1952. (Source: Author, based on data from the Government of Japan)

$20 \%$ in the mid-1970s. We used this measure as there is no long-term time series data on poverty in Japan because there was no official definition of the poverty line until 2009. Although the Ministry of Welfare published estimated poverty rates from 1953 to 1965 based on a comprehensive survey of living conditions, they terminated its publication in the mid1960s. This was because it was thought that poverty was no longer an issue in Japan. Therefore, instead of the poverty ratio, this chapter uses "the ratio of households on welfare" as, even if this data is technically not very precise with respect to the poverty ratio, at least it can show us the trend of poverty over time. The ratio of households on welfare dropped to less than 15\% in the early 1990s. Therefore, it appears that Japan's economic growth was pro-poor growth, especially during the rapid growth period from the 1960s to the 1980s.

East Asia including Japan is known for its record of high and sustained economic growth, as the World Bank (1993) discussed. This was also characterized by highly equal income distributions (Birdsall and Sabot 1993). ${ }^{13}$ To develop its economy, soon after World War II, Japan developed an 
industrial policy called the priority production system and made huge investments in infrastructure. Both of these policy measures were the basis for Japan's high economic growth. These policies, however, do not explain why Japan's economic recovery after the war was inclusive. Economic growth does not necessarily become inclusive. The keys to understanding the inclusiveness were the tension with the labor union and the introduction of the productivity movement (later called Kaizen because of this tension). The introduction of Kaizen made Japan's economic growth inclusive (Shimada 2015b, 2017a; Shimada and Motomura 2017).

\section{Conclusions and Policy Implications}

As we have seen in this chapter, Japan created a social innovation through the process of conflict and negotiation between labor and employers to share the profits equitably. This innovation not only improved the lives of people but also strengthened the competitiveness of firms. This is because employees became loyal to the firms they belong to with lifetime employment and company-specific labor unions (most Japan's labor unions are not organized by industry). Under life-time employment, the prospect of wage increases raises labors' motivation to work. This is not technological innovation, but an innovation to boost firm performance and, hence, economic growth. This win-win situation, achieving economic growth and equality, was a social innovation. Developing countries as well as developed countries need this social innovation to tackle the issue of inequality in the age of globalization and rapid economic growth. As we have seen in this chapter, Kaizen is essential knowledge, a missing piece, for both developed and developing countries to achieve equitable growth.

\section{Notes}

1. These include Courtney Whitney (Chief of the Government Section), Charles Louis Kades (Chief and Deputy Chief of the Government Section), and Thomas Arthur Bisson (Top Economic Analyst).

2. Mr. Yoshida singled out T.A. Bisson for special criticism (Schonberger 1980).

3. Land was confiscated in 1946 and 1947. This land reform reduced income inequality and expanded the middle class a lot. 
4. For details of the discussion of this section, please see Shimada $(2017 \mathrm{~b}$, 2018a).

5. The official SCAP index is based on the low 1930-1934 levels of production output. Bisson $(1949,104)$ mentioned that the UN index is a better measurement since Japan needed to reach at least the 1937 level of production to become economically self-supporting.

6. Following the hyperinflation, Japan was forced to adopt austerity measures, called the Dodge Plan, by the United States.

7. Bisson regarded the hyperinflation Japan suffered during this period as a result of conscious and deliberate policies of the conglomerates and bureaucrats. The various taxes against big stockholders became meaningless with a devalued yen. Further, he argued the inflation raised stock valuation of those companies, generating more gains (Schonberger 1980)

8. Bisson $(1949,44)$ mentioned that: "The Communists were the one group that could point to a consistent record of opposition to Japanese militarism and the war. This factor helped them to muster popular support as soon as their leaders were released from prison."

9. Bisson $(1949,74)$ recalled that: "...the occupant authorities became increasingly disturbed by the 'left-wing' character of the programs sponsored by the new political parties. And after the first election in April 1946, the emphasis of occupant policy was placed on controlling rather than encouraging the growth of the popular movement."

10. Because of this change in policy, as Dower (2000) described, communist leaders, such as Tokuda, were embarrassed. Because of this, when they were released in October 1945, he read "Appeal to the People" that said: "We express our deepest gratitude that the occupation of Japan by the Allied forces, dedicated to liberating the world from fascism and militarism, has opened the way for the democratic revolution in Japan." Later, the communists were forced to justify his statement, saying that the reference to "Allies" included the Soviet Union.

11. With the aid from the United States, productivity centers were established all around Europe: UK (1948), Denmark (1949), Turkey (1949), Austria (1950), West Germany (1950), Netherlands (1950), Trieste (1950), Belgium (1951), Italy (1951), Switzerland (1951), Greece (1953), Sweden (1953), France (1954), among others (Shimada 2018a).

12. This is one of precursor organizations to the USAID (United States Agency for International Development).

13. Some academic papers have estimated the poverty rate. For instance, Otake (2003) estimated that the Gini coefficient very rapidly improved, especially in the $1960 \mathrm{~s}$. The coefficient was 0.31 in 1963 , and it had become 0.25 by 1971. 


\section{REFERENCES}

Arrow, Kenneth J. 1962a. Economic Welfare and the Allocation of Resources for Innovation. In The Rate and Direction of Inventive Activity: Economic and Social Factors, ed. R. Nelson and National Bureau of Economic Research, 609629. Princeton, NJ: Princeton University Press.

- 1962b. The Economic Implications of Learning by Doing. Review of Economic Studies 29: 155-173.

Baily, Martin Neil, Charles Hulten, David Campbell, Timothy Bresnahan, and Richard E. Caves. 1992. Productivity Dynamics in Manufacturing Plants. Brooking Papers on Economic Activity: Microeconomics 23: 187-267.

Baily, Martin Neil, and Robert M. Solow. 2001. International Productivity Comparisons Built from the Firm Level. Journal of Economic Perspective 15 (3): 151-172.

Birdsall, N., and R.H. Sabot. 1993. Virtuous Circles: Human Capital Growth and Equity in East Asia. Background Paper for The East Asian Miracle. Washington, DC: World Bank, Policy Research Department.

Bisson, T.A. 1949. Prospects for Democracy in Japan. New York: Macmillan.

Dower, John. W. 2000. Embracing Defeat: Japan in the Wake of World War II. Kindle ed. W. W. Norton \& Company.

Higuchi, Yuki, and Shimada Go. 2019. Industrial Policy, Industrial Development and Structural Transformation in Asia and Africa. In Paths to the Emerging State in Asia and Africa, Emerging-Economy State and International Policy Studies, ed. Keijiro Osuka and Kaoru Sugihara. Singapore: Springer.

Milanović, B. 2016. Global Inequality: A New Approach for the Age of Globalization. Cambridge, MA: Harvard University Press.

Otake, F. 2003. Was There the Expansion of Income Inequality? In Income Inequality and Social Hierarchy in Japan, ed. Y. Higuchi and The Ministry of Finance. Tokyo: Nihon Hyoronsha.

Piketty, T. 2014. Capital in the 21st Century. Cambridge, MA: Harvard University Press.

Schonberger, H. 1980. Thomas Arthur Bisson and the Limits of Reforms in Occupied Japan. Bulletin of Concerned Asian Scholars 12 (4): 26-37.

Shimada, Go. 2015a. The Economic Implications of Comprehensive Approach to Learning on Industrial Development (Policy and Managerial Capability Learning): A Case of Ethiopia. In Industrial Policy and Economic Transformation in Africa, ed. Akbar Noman and Joseph Stiglitz. New York: Columbia University Press.

- 2015b. The Role of Social Capital after Disasters: An Empirical Study of Japan based on Time-Series-Cross-Section (TSCS) Data from 1981 to 2012. International Journal of Disaster Risk Reduction 14: 388-394.

- 2017a. A Quantitative Study of Social Capital in the Tertiary Sector of Kobe-Has Social Capital Promoted Economic Reconstruction since the Great 
Hanshin Awaji Earthquake? International Journal of Disaster Risk Reduction 22: 494-502.

- 2017b. Inside the Black Box of Japan's Institution for Industrial PolicyAn Institutional Analysis of Development Bank, Private Sector and Labor. In Efficiency, Finance and Varieties of Industrial Policy, ed. Akbar Noman and Joseph Stiglitz. New York: Columbia University Press.

- 2018a. The US Aid Strategy for Productivity Improvement in Japan after World War II with a Focus on Labor Unions: Japan's Experience as a Recipient Country. Journal of International Development Studies 27 (2): 69-84.

- 2018b. United States' Aid to Japan in the Postwar Era for Improving Productivity-From Recipient Country to Donor Country. Tokyo: JICA Research Institute.

- 2019. Does Environmental Policy Make African Industry Less Competitive?-The Possibilities in Green Industrial Policy. In The Quality of Growth in Africa, ed. Ravi Kanbur, Akbar Norman, and Joseph Stiglitz. New York: Columbia University Press.

Shimada, Go, and Miki Motomura. 2017. Building Resilience through Social Capital as a Counter-Measure to Natural Disasters in Africa: A Case Study from a Project in Pastoralist and Agro-pastoralist communities in Borena, in the Oromia Region of Ethiopia. Africa Study Monograph. Supplement Issue No. 53: 35-51.

Shimada, Go, and Tetsushi Sonobe. 2018. Impacts of Kaizen Management on Workers: Evidence from the Central America and Caribbean Region. JICA-RI Working Paper (173).

Solow, Robert M. 1956. A Contribution to the Theory of Economic Growth. Quarter Journal of Economics 70: 65-94.

. 1957. Technical Change and the Aggregate Production Function. Review of Economics and Statistics 39 (3): 312-320.

Stiglitz, Joseph, and Bruce C. Greenwald. 2015. Creating a Learning Society: A New Approach to Growth, Development and Social Progress. New York: Columbia University Press.

Tsunekawa, Keiichi. 2010. State-Building, Economic Development, and Democracy: The Japanese Experience. World Development Report 2011 Background Case Note. Tokyo: JICA Research Institute.

World Bank. 1993. The East Asian Miracle-Economic Growth and Public Policy. Oxon: Oxford University Press. 
Open Access This chapter is licensed under the terms of the Creative Commons Attribution 4.0 International License (http://creativecommons.org/licenses/ by $/ 4.0 /$ ), which permits use, sharing, adaptation, distribution and reproduction in any medium or format, as long as you give appropriate credit to the original author(s) and the source, provide a link to the Creative Commons licence and indicate if changes were made.

The images or other third party material in this chapter are included in the chapter's Creative Commons licence, unless indicated otherwise in a credit line to the material. If material is not included in the chapter's Creative Commons licence and your intended use is not permitted by statutory regulation or exceeds the permitted use, you will need to obtain permission directly from the copyright holder.

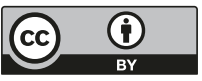

